Ratna Kusuma Astuti, Ganik Sakitri. Pengaruh Pendidikan Kesehatan terhadap Peningkatan Pengetahuan Santriwati tentang Deteksi Dini Kanker Payudara di Pondok Pesantren Rodhotul Jannah

\title{
PENGARUH PENDIDIKAN KESEHATAN TERHADAP PENINGKATAN PENGETAHUAN SANTRIWATI TENTANG DETEKSI DINI KANKER PAYUDARA DI PONDOK PESANTREN RODHOTUL JANNAH
}

\author{
Ratna Kusuma Astuti ${ }^{1}$ \\ Politeknik Insan Husada Surakarta \\ Corresponding Author Email : nana100389@gmail.com \\ Ganik Sakitri \\ Politeknik Insan Husada Surakarta \\ Corresponding Author Email : ganiksakitri2312@gmail.com
}

\begin{abstract}
ABSTRAK
SADARI merupakan salah satu cara mudah untuk melakukan deteksi dini kanker payudara pada wanita setelah mesntruasi dengan melakukan pemeriksaan payudara sendiri. Pemeriksaan payudara sendiri dapat meningkatkan kesadaran akan pentingnya kewaspadaan adanya benjolan yang tidak normal pada payudara. Penelitin ini bertujuan untuk mengetahui pengaruh Pendidikan Kesehatan terhadap peningkatan pengetahuan santriwati tentang deteksi dini kanker payudara di Pondok Pesantren Rodhotul Jannah. Metode penelitian menggunakan pre eksperimental dengan one grup prepost test design. Responden pada penelitian ini menggunakan total sampling dengan jumlah responden 15 santriwati. Responden diukur dengan menggunakan kuesioner pengetahuan, selanjutnya diberikan Pendidikan Kesehatan dalam bentuk penyuluhan kemudian responden diukur lagi menggunakan kuesioner pengetahuan yang sama. Hasil analisis data menggunakan uji statistik Wilcoxon Signed Ranks Test $(\alpha=0,05)$ didapatkan nilai probabilitas $=0,000$. Hal ini menunjukkan nilai $p<$ nilai $\alpha$. Hasil penelitian dapat disimpulkan bahwa ada pengaruh Pendidikan Kesehatan terhadap peningkatan pengetahuan santriwati tentang deteksi dini kanker payudara di Pondok Pesantren Rodhotul Jannah.
\end{abstract}

Kata Kunci : Pendidikan Kesehatan, pengetahuan, SADARI

\section{ABSTRACT}

SADARI is an easy way to do early detection of breast cancer in women after menstruation by doing breast self-examination. Breast self-examination can increase awareness of the importance of being aware of an abnormal lump in the breast. This study aims to determine the effect of Health Education on increasing the knowledge of female students about early detection of breast cancer at the Rodhotul Jannah Islamic Boarding School. The research method used preexperimental with one group pre-posttest design. Respondents in this study used total sampling with a total of 15 female students as respondents. Respondents were measured using a knowledge questionnaire, then health education was given in the form of counseling and then respondents were measured again using the same knowledge questionnaire. The results of data analysis using the Wilcoxon Signed Ranks test statistic $(\alpha=0.05)$ obtained a probability value of 0.000 . This shows the value of $p<$ value of. The results of the study concluded that there was an effect of Health Education on increasing the knowledge of female students about early detection of breast cancer at the Rodhotul Jannah Islamic Boarding School.

Keywords : Health Education, knowledge, SADARI

\section{PENDAHULUAN}

Kanker payudara metupakan salah satu penyakit tidak menular yang menjadi penyebab kematian terbanyak di kalangan wanita. Kanker payudara di definisikan sebagai salah satu patologi yang dimulai dengan perunahan genetic pada sel tunggal (Jonhson, 2010). Perubahan genetic pada sel tunggal disebabkan karena adanya pertumbuhan yang berlebihan dan perkembangan yang tidak terkontrol dari selsel jaringan payudara sehingga memerlukan watu beberapa tahuan untuk dapat terpalpasi dengan pertumbuhan yang berawal dari tumor sebesar $1 \mathrm{~cm}$ namun dalan kurun waktu 8-12 tahun sel pemicu akan tumbuh dalam tubuh inang (Mulyani, 2013). 
Ratna Kusuma Astuti, Ganik Sakitri. Pengaruh Pendidikan Kesehatan terhadap Peningkatan Pengetahuan Santriwati tentang Deteksi Dini Kanker Payudara di Pondok Pesantren Rodhotul Jannah

International Agency Cancer Registry (IACR) tahun 2012 menjelaskan bahwa kanker payudara menempati urutan pertama dari seluruh kanker pada wanita (incidence rate 38 per 100.000 wanita), kasus baru yang ditemukan $22,7 \%$ dengan jumlah kematian $14 \%$ setiap tahun dari seluruh kasus kanker pada wanita di dunia. Hal yang sama terjadi dimana kanker tertinggi yang diderita wanita di Indonesia adalah kanker payudara dengan angka kejadian 26 per 100.000 wanita. Berdasarkan data system Informasi Rumah Sakit (SIRS) tahun 2012. Kanker payudara menempati urutan pertama pada pasien rawat inap di seluruh RS di Indonesia (21,69\%) (Departemen Kesehatan RI, 2013).

Prevalensi penderita kanker semua kelompok umur di Indonesia sebesar 1,4\%. Provinsi Jawa Tengah menempati urutan kedua dengan prevalensi 2,1\%. Angka tersebut merupakan rata-rata kasus yang lebih tinggi dibandingkan dengan angka nasional (Departement Kesehatan RI, 2012).

Pemeriksaan payudara sendiri (SADARI) merupakan salah satu deteksi dini kanker payudara dengan cara meraba area payudara secara teratur sehingga dapat mengetahui dan merasakan perubahan abnormal pada payudara (WHO, 2018). SADARI dapat dilakukan sejak usia 18-20 tahun, SADARI dapat dilakukan pada hari ketujuh samapi hari kesepuluh setelh menstruasi karena pada saat ini pengaruh estrogen dan progresteron sangat rendah dan kelenjar payudara dalam keadaan tidak membengkak (Putra, 2015).

Tujuan dari penelitian ini adalah untuk mengetahui pengaruh Pendidikan Kesehatan terhadap peningkatan pengetahuan santriwati tentang deteksi dini kanker payudara di Pondok Pesantren Rodhotul Jannah. Adapun hasil penelitian ini diharapkan dapat menambah informasi bagi responden, sehingga menjadi bahan pertimbangan dalam meningkatkan pengetahuan tentang deteksi dini kanker payudara.

\section{METODE PENELITIAN}

Penelitian ini dilaksanakan di Pondok Pesantren Rodhotul Jannah pada bulan Agustus tahun 2021. Penelitian ini menggunakan pre-experimental design dengan one grup prepost design. Populasi pada penelitian ini adalah santriwati Pondok
Rodhotul Jannah sejumlah 15 santriwati. Pengambilan sampel yang digunakan adalah dengan metode total sampling sehingga semua santriwati dijadikan sebagai responden penelitian. Dengan kriteria inklusi santriwati belum pernah mendaparkan Pendidikan Kesehatan tentang deteksi dini kanker payudara dan bersedia menjadi responden dengan menyetujui informed consent.

Tahap pelaksanaan penelitian meliputi: mengajukan permohonan ijin penelitian di Pondok Pesantren Rodhotul Jannah. Peneliti mengumpulkan data dan menyebarkan kuesioner yang diambil dari penelitian sebelumnya yang telah dibakukan dan diuji validitas. Santriwati yang menjadi responden dalam penelitian ini diberikan penjelasan mengenai tujuan penelitian yang sedang dijalankan dan harus menandatangi informed concern.

Pada saat pengisian kuesioner, responden dituntun oleh peneliti. Setelah data terkumpul, peneliti kemudian melakukan kegiatan sebagai berikut: seleksi, editing, koding dan membuat tabel. Untuk data yang telah dikelompokkan, selanjutnya data diolah dan dianalisis dengan menggunakan tabel distribusi yang dikonfirmasikan dalam bentuk prosentase. Analisis data menggunakan analisis univariat dan analisis bivariat. Analisis univariat dilakukan pada setiap variable dari hasil penelitian. Analisis bivariat dilakukan dengan menggunakan uji Wilcoxon Signed Ranks Test.

Instrument dalam penelitian ini adalah menggunakan kuesioner. Kuesioner diberikan kepada responden yang bersedia memberikan jawaban sesuai dengan permintaan peneliti. Pada kuesioner ada 10 pertanyaan positif. Bila jawaban benar diberikan skor 1 dan bila jawaban salah diberikan skor 0 . Tingkat pengetahuan tentang deteksi dini kanker payudara yang diperoleh melalui pengisian kuesioner dikategorikan menjadi 2 (dua) yaitu: tinggi dengan jawaban $66-100 \%$ dan rendah dengan jawaban $<66 \%$

\section{HASIL}

\section{Pengetahuan berdasarkan Umur}

Responden

Tabel 1. Distribusi Frekuensi Responden berdasarkan umur 
Ratna Kusuma Astuti, Ganik Sakitri. Pengaruh Pendidikan Kesehatan terhadap Peningkatan Pengetahuan Santriwati tentang Deteksi Dini Kanker Payudara di Pondok Pesantren Rodhotul Jannah

\begin{tabular}{lll}
\hline Kategori & $\mathrm{N}$ & $\%$ \\
\hline $16-18$ tahun & 10 & $66,7 \%$ \\
$19-21$ tahun & 5 & $33,3 \%$ \\
Total & 15 & $100 \%$ \\
\hline
\end{tabular}

Tabel 1 diatas menyatakan bahwa kategori usia 16-18 tahun sejumlah 10 santriwati $(66,7 \%)$ dan kategori usia 19 21 tahun sejumlah 5 santriwati $(33,3 \%)$. Umur mempengaruhi daya tangkap dan pola piker seseorang. Semakin bertambah umur akan semakin berkembang pula daya tangkap dan pola pikirnya, sehingga pengetahuan yang diperoleh semakin baik.

\section{Pengetahuan Responden tentang} Deteksi Dini Kanker payudara

Tabel 2 distribusi Frekuensi Responden berdasarkan pengetahuan

\begin{tabular}{lll}
\hline Kategori & $\mathrm{N}$ & $\%$ \\
\hline Pre & & \\
Tinggi & 3 & $20 \%$ \\
Rendah & 12 & $80 \%$ \\
Total & 15 & $100 \%$ \\
\hline Post & & \\
Tinggi & 15 & $100 \%$ \\
Rendah & 0 & $0 \%$ \\
Total & 15 & $100 \%$ \\
\hline
\end{tabular}

Tabel 2 diatas menyatakan bahwa pengetahuan santriwati sebelum diberikan pendidikan kesehatan tentang deteksi dini kanker payudara kategori tinggi sejumlah 3 santriwati (20\%) dan kategori rendah sejumlah 12 santriwati (80\%). Sedangkan hasil pengetahuan santriwati setelah diberikan pendidikan kesehatan tentang deteksi dini kanker payudara kategori tinggi sejumlah 15 santriwati $(100 \%)$ dan kategori rendah sejumlah 0 santriwati $(0 \%)$.

3. Analysis Pengaruh Pendidikan Kesehatan terhadap peningkatan Pengetahuan Santriwati tentang Deteksi Dini Kanker Payudara

\begin{tabular}{llllll}
\hline & $\mathrm{N}$ & Mean & Min & Max & Sig \\
\hline Pre & 15 & 9.4 & 4.0 & 14.0 & 0.0 \\
Post & 15 & 14.3 & 8.0 & 15.0 & 0.0 \\
\hline
\end{tabular}

Tabel 3 diketahui bahwa Nilai asymp.sig. (2-tailled) $<0,05$ maka Ha diterima artinya ada perbedaan hasil pengetahuan pretest dan posttest dimana setelah diberikan pendidikan kesehatan tentang deteksi dini kanker payudara hasil postest nilainya lebih tinggi dibandingkan hasil pretest.

\section{PEMBAHASAN}

1. Pengetahuan berdasarkan Umur

Responden

Tabel 1 menyatakan bahwa kategori usia 16-18 tahun sejumlah 10 santriwati $(66,7 \%)$ dan kategori usia 19-21 tahun sejumlah 5 santriwati $(33,3 \%)$. Umur mempengaruhi daya tangkap dan pola piker seseorang. Semakin bertambah umur akan semakin berkembang pula daya tangkap dan pola pikirnya, sehingga pengetahuan yang diperoleh semakin baik.

Umur mempunyai kaitan dengan mudah sulitnya seseorang memahami dan menerima serta melaksanakan sesuatu yang diinformasikan, baik berupa saran, penyampaian, pengumuman maupun penyuluhan. Biasanya orang yang dikategorikan dewasa lebih mudah menerima dan memahami informasi-informasi yang disampaikan dari sumber apapun, dimana proses daya tangkap yang dimiliki masih tinggi. Factor umur juga dapat dikatkan dengan tingkat pengetahuan seseorang, dalam hal ini adalah muda tuanya seseorang. Pada dasarnya, umur melatar belakangi penentuan pengetahuan.

\section{Pengetahuan Responden tentang Deteksi Dini Kanker payudara}

Tabel 2 menyatakan bahwa pengetahuan santriwati sebelum diberikan pendidikan kesehatan tentang deteksi dini kanker payudara kategori tinggi sejumlah 3 santriwati (20\%) dan kategori rendah sejumlah 12 santriwati $(80 \%)$. Sedangkan hasil pengetahuan santriwati setelah diberikan pendidikan kesehatan tentang deteksi dini kanker payudara kategori tinggi sejumlah 15 santriwati $(100 \%)$ dan kategori rendah sejumlah 0 santriwati $(0 \%)$.

Pengetahuan merupakan hasil dari tahu dan ini terjadi setelah seseorang melakukan penginderaan terhadap objek tertentu. Penginderaan terhadap 
objek terjadi melalui panca indera manusia, yakni: indera penglihatan, indera pendengaran, indera pendiuman, indera perasa dan indera peraba. Sebagian besar pengetahuan manusia diperoleh melalui mata dan telinga.

Noroatmodjo (2012) menjelaskan bahwa terbentuknya perilaku baru terutama pada orang dewasa dimulai pada domain kognitif dalam arti subjek tahu terlebih dahulu dalam bentuk sikap. Akhirnya rangsangan objek yang telah diketahui dan disadari sepenuhnya tersebut akan menimbulkan respon lebih jauh lagi yaitu berupa Tindakan terhadap stimulus atau objek. Meskipun tingkat pengetahuan akan sangat berpengaruh terhadap penerimaan suatu program, akan tetapi kurangnya informasi terhadap suatu program juga berpengaruh terhadap tingkat penerimaannya.

Semakin tinggi pengetahuan seseorang akan cenderung membentuk sikap positif yang lebih besar. Sehingga akan membentuk perubahan sikap dan timbul terjadinya perubahan perilaku.

Pada penelitian ini masih terdapat tingkat pengetahuan tentang deteksi dini kanker payudara yang kurang. Hal ini bisa disebabkan oleh beberapa faktor diantaranya faktor pengalaman yang mempengaruhi pengetahuan seseorang dan tergantung pada ingatan seseorang pada saat pengisisan kuesioner. Sesuai dengan penjelasan Notoadmodjo (2012), bahwa faktor-faktor yang mempengaruhi pengetahuan diantaranya pendidikan, informasi/media massa, pekerjaan, lingkungan, pengalaman, usia, sosial, budaya dan ekonomi.

\section{Analisis Pengaruh Pendidikan Kesehatan terhadap peningkatan Pengetahuan Santriwati tentang Deteksi Dini Kanker Payudara \\ Tabel 3 diketahui bahwa Nilai} asymp.sig. (2-tailled) $<0,05$ maka $\mathrm{Ha}$ diterima artinya ada perbedaan hasil pengetahuan pretest dan posttest dimana setelah diberikan pendidikan kesehatan tentang deteksi dini kanker payudara hasil postest nilainya lebih tinggi dibandingkan hasil pretest.

Penelitian ini sejalan dengan penelitian yang telah dilakukan Syaiful $Y$ dan Aristrantia (2016) yang mengatakan bahwa terdapat pengaruh sebelum dan setelah pendidikan kesehatan terhadap kemampuan siswi dalam melakukan pemeriksaan payudara sendiri. Hal ini sebagaiupaya pencegahan kanker payudara, dimana hasil skor kemampuan melakukan SADARI sebelum diberi pendidikan kesehatan lebih rendah secara bermakna dibanding skor setelah diberi pendidikan kesehatan meningkat. Peningkatan kemampuan ini salah satunya dipengaruhi oleh minat peserta didik, dimana siswi termotivasi untuk mampu mendeteksi dini kanker payudara dan mencegah kematian akibat kanker payudara. Adanya pemberian pendidikan kesehatan tentang pemeriksaan payudara sendiri mampu meningkatkan motivasi pada wanita dalam melakukan deteksi dini kanker payudara Syaiful.Y \& Aristantia (2016).

Kesadaran untuk melakukan SADARI penting ditumbuhkan untuk memotivasi seseorang agar secara teratur melakukan SADARI untuk mengidentifikasi secara dini benjolan abnormal pada payudaranya sehingga dapat segera diobati dan menurunkan kematian akibat kanker payudara Hidayanti (2018). Tingginya minat seseorang terhadap informasi yang sebelumnya mereka belum pernah mendengar dan mendapatkannya maka seseorang akan lebih termotivasi dalam pemberian pendidikan kesehatan. Pendidikan kesehatan dengan metode demonstrasi dapat meningkatkan kemampuan pada siswi karena metode ini melibatkan seluruh indra untuk menerima informasi dan diberikan secara langsung oleh peneliti tentang pemeriksaan payudara seharihari.

\section{KESIMPULAN}

Berdasarkan hasil penelitian yang telah dilakukan dan disajikan dapat disimpulkan sebagai berikut:

1. Karakteristik umur santriwati di Pondok Pesantren Rodhotul Jannah. Kategori 
Ratna Kusuma Astuti, Ganik Sakitri. Pengaruh Pendidikan Kesehatan terhadap Peningkatan Pengetahuan Santriwati tentang Deteksi Dini Kanker Payudara di Pondok Pesantren Rodhotul Jannah

umur 16-18 tahun sejumlah 10 santriwati $(66,7 \%)$ dan kategori umur 19-21 tahun sejumlah 5 santriwati $(33,3 \%)$.

2. Nilai rata-rata sebelum diberikan pendidikan kesehatan tentang deteksi dini kanker payudara sebesar 9.4 sedangkan setelah diberikan pendidikan kesehatan tentang deteksi dini kanker payudara diperoleh nilai rata-rata sebesar 14.3. Terjadi peningkatan nilai rata-rata sebesar 4.9.

3. Ada pengaruh pendidikan kesehatan terhadap peningkatan pengetahuan tentang deteksi dini kanker payudara di Pondok Pesantren Rodhotul Jannah.

\section{SARAN}

1. Bagi Profesi

Melanjutkan dan meningkatkan perhatian terhadap pendidikan kesehatan bagi perempuan khususnya tentang kanker payudara dan tindakan preventif serta promotif yaitu dengan SADARI.

2. Bagi Santriwati

Meningkatkan tindakan preventif secara mandiri dan sedini mungkin dengan cara meningkatkan pengetahuan tentang kanker payudara dan keterampilan tentang SADARI dan mengaplikasikannya dalam kehidupan sehari-hari.

\section{DAFTAR PUSTAKA}

Hidayanti Aprilia. 2018. Pengaruh Pendidikan Kesehatan Melalui Metode Ceramah dan Demonstrasi dalam Meningkatkan Pengetahuan Tentang Kanker Payudara dan Keterampilan Praktik SADARI. Jurnal Universitas Muhammadiyah Semarang.

Lestari, H dkk. 2021. Efektifitas Promosi Kesehatan Terhadap Peningkatan Pengetahuan Ibu Tentang Deteksi Dini Kanker Payudara. Jurnal IImiah Permas: Jurnal Kendal, 11(1). 31-32.

Maulana. 2009. Promosi Kesehatan. Jakarta: Penerbit EGC.

Marfiah, E. 2021. Peningkatan Pengetahuan Kanker Payudara dan Ketrampilan
SADARI di Semutan Jatimulyo Dlingo. JAMALI. 3(10). 25-31.

Notoatmodjo, Soekidjo. 2012. Pendidikan dan Perilaku Kesehatan. Jakarta: Rineka Cipta.

Putra, S.R. 2015. Buku Lengkap Kanker Payudara. Yogyakarta: Laksana.

Riset Kesehatan Dasar (Riskesdas). 2018. Badan Penelitian dan. Pengembangan Kesehatan Kementerian RI tahun 2018. Jakarta: Badan Penelitian dan Pengembangan Kesehatan Kementerian Kesehatan Republik Indonesia. From: https://kesmas.kemkes.go.id/assets/u pload/dir 519d41d8cd98f00/files/Hasi Iriskesdas-2018 1274.pdf

Savitri, dkk. 2015. Hubungan Stadium Kanker Payudara Dengan Stres Pada Pasien Kanker Payudara Di Rsi Sultan Agung Semarang. From: http://repository.unimus.ac.id/896/3/B $\underline{A B \% 2011 . p d f}$

Syaiful.Y \& Aristantia. 2016. Pendidikan Kesehatan Pemeriksaan Payudara Sendiri Terhadap Perilaku SADARI Pada Remaja. Journal of Ners Community.

Savitri, A, dkk. 2015. Kupas Tuntas Kanker Payudara, Leher Rahim dan Rahim. Yogyakarta: Pustaka Baru Press.

Septiani, Suara Dalam Tri Viviyawati. 2014. Pengaruh Pendidikan Kesehatan Tentang Pemeriksaan Payudara Sendiri (SADARI) Sebagai Deteksi Dini Kanker Payudara Terhadap Pengetahuan dan Sikap Remaja Putri di SMKN 1 Karanganyar. Skripsi. Fakultas Keperawatan Stikes Kusuma Husada Surakarta. From: http://lp3m.thamrin.ac.id/upload/arti 
Ratna Kusuma Astuti, Ganik Sakitri. Pengaruh Pendidikan Kesehatan terhadap Peningkatan Pengetahuan Santriwati tentang Deteksi Dini Kanker Payudara di Pondok Pesantren Rodhotul Jannah

Sulisna. 2009. Pengaruh Pendidikan Kesehatan Terhadap Tingkat Pengetahuan Siswi Tentang SADARI sebagai deteksi Dini Kanker Payudara Di SMA Negri 1 Manado. E-journal Keperawatan. Vol.1. No.1. Agustus 2013. 